\title{
Performance of Boro Rice in Response to Different Application Methods of Urea Fertilizer
}

\author{
Ashick Ahmed ${ }^{1 *}$, Md. Mahbubur Rashid ${ }^{1}$, Md. Julfiker Rahman', Md. Sirajul Islam² \\ ${ }^{1}$ BRAC Agricultural Research and Development Centre, Joydebpur, Gazipur-1701, Bangladesh \\ ${ }^{2}$ Agriculture and Food Security Programme, BRAC, 75, Mohakhali, Dhaka-1212, Bangladesh
}

\section{A R T I C LE IN F O}

\section{Research Article}

Received 31 January 2018

Accepted 21 March 2018

\section{Keywords:}

Boro rice

Urea fertilizer application methods

Growth parameters

Yield

Green Super Rice

${ }^{*}$ Corresponding Author:
E-mail: ashick.ahmed@brac.net
\begin{abstract}
A B S T R A C T
$\mathrm{N}$ (nitrogen) is an essential element that is very complex to manage. Adjustment to different application methods of $\mathrm{N}$ containing urea can be a crucial option for effective management of $\mathrm{N}$. The experiment was carried out at the BRAC Agricultural Research and Development Centre, Gazipur during 2012/2013 and 2013/2014 growing seasons with the objectives to find out the response of genotypes and different urea fertilizer application methods on growth parameters, yield and yield attributes of Boro rice. The experiment was arranged in split-plot design with three replications having two genotypes viz. (i) $\mathrm{V}_{1}=$ GSR I Sal Y 1242 and (ii) $\mathrm{V}_{2}=$ BRRI dhan 28 placed in main plot and four urea application methods viz. (i) $\mathrm{T}_{1}=220 \mathrm{~kg} \mathrm{ha}^{-1} \mathrm{PU}$ at three equal splits (ii) $\mathrm{T}_{2}=2 \%$ foliar spray @ $80 \mathrm{~kg} \mathrm{ha}^{-1}$ (iii) $\mathrm{T}_{3}=75 \mathrm{~kg} \mathrm{~N} \mathrm{ha}^{-1} \mathrm{USG}\left(2.7 \mathrm{~g}\right.$ ) and (iv) $\mathrm{T}_{4}=\mathrm{LCC}$ based urea @ $67.5 \mathrm{~kg} \mathrm{ha}^{-1}$ placed in sub plot. Results showed that genotypes had non-significant influence for most of the growth parameters and yield components, whereas urea fertilizer application methods had significant effect on all growth parameters, yield and yield attributes except plant height at 40 DAT and 50\% flowering stage. . With different methods of urea application, $\mathrm{T}_{4}$ achieved significantly the highest value of all growth parameters, yield and yield components with total $\mathrm{N}_{\text {content }}$ hill-1 ${ }^{-1}(3.859 \%)$ and harvest index $(50.70 \%)$ except filled grain panicle ${ }^{-1}(82.98)$ at harvest. Among the interactive treatments, the highest number of tillers $\mathrm{m}^{-2}$ (351.66), dry weight hill ${ }^{-1}(88.13 \mathrm{~g})$, panicle number $\mathrm{m}^{-2}(340.83)$, panicle length $(23.33 \mathrm{~cm})$ and grain yield $\left(7.32 \mathrm{t} \mathrm{ha}^{-1}\right)$ was obtained at $\mathrm{V}_{1} \mathrm{~T}_{4}$. So, in aspect of yield and other parameters, $\mathrm{V}_{1} \mathrm{~T}_{4}$ was the best treatment under the present study.
\end{abstract}

DOI: https://doi.org/10.24925/turjaf.v6i7.869-876.1826

\section{Introduction}

Management of $\mathrm{N}$ in farming systems is difficult because of the interactions between soil mineralization potential, soil water availability and the type of crops grown (Hatfield, 2004). Rice (Oryza sativa L.) is the main food crop of Bangladesh and it covers about $80 \%$ of the total cropped area of the country (AIS, 2008). The area and production of rice in Bangladesh is about 11.35 million hectares and 31.98 million MT, respectively where Boro covers the largest part of about 4.7 million hectares with the production of 18.06 million MT (BBS, 2010). However, the average grain yield in the country is much lower (2.94 $\mathrm{t} \mathrm{ha}^{-1}$ ) (BBS, 2012). Among the various reasons for low yield, judicious fertilizer management is one of them (Yoshida, 1981). The optimum use of $\mathrm{N}$ can be achieved by matching $\mathrm{N}$ supply with crop demand (Bijay et al., 2002). Farmers generally apply nitrogen fertilizer in fixed time recommended $\mathrm{N}$ split schedule (Pillai and Kundu, 1993) in 1:2:1 or 2:1:1 ratio at basal, maximum tillering and panicle initiation stages respectively, without taking into account whether the plants really require $\mathrm{N}$ at that time, which may lead to loss or may not be found adequate enough to synchronize nitrogen supply with actual crop nitrogen demand (Ladha et al., 2000). Among the fertilizers, nitrogen is the major essential plant nutrient and key input for rice production and increasing yield in Bangladesh (Hasan et al., 2002). Dastan et al. (2012) reported that $\mathrm{N}$ is the most important and essential plant nutrients to increase the crop yield positively.

Prilled urea (PU) is the most commonly used nitrogenous fertilizer for rice cultivation in Bangladesh. The efficiency of nitrogenous fertilizer especially, PU in rice cultivation is about $25-30 \%$ and rest $70-75 \%$ is lost for many reasons after application (BRRI, 2008). PU is a very fast releasing nitrogenous fertilizer that usually broadcasted in splits, can cause a considerable as ammonia volatilization, de-nitrification, surface run-off and leaching etc (De Datta, 1978). It was observed that Urea Super Granule (USG) can minimize the loss of nitrogen from the soil and hence the affectivity increased up to 20-25\% (BRRI, 2008). Placement of USG in the 
root zone is the most effective method for increasing the nitrogen use efficiency and rice yield (Prasad et al., 1982; Sharma, 1995). Urea can also be supplied to plants through the foliage, facilitating optimal nitrogen management, which minimize nitrogen losses to the environment without affecting yield (Millard and Robinson, 1990). Most plants absorb foliar applied urea rapidly (Wittwer et al., 2002; Nicoulaud and Bloom, 1996) and hydrolyze the urea in the cytosol. Farmer's application of $\mathrm{N}$ does not coincide with the critical growth stages and proper amount may not be always maintained. Therefore, to provide an optimum $\mathrm{N}$ schedule to the farmers proper monitoring of $\mathrm{N}$ is required. $\mathrm{N}$ requirements vary among crop varieties (Raut, 2007). Rice leaf colour chart (LCC) can be used for adjustment of $\mathrm{N}$ application based on actual plant $\mathrm{N}$ status (Balasubramanian et al., 1999). LCC acts as a visual and subjective indicator of crop need for $\mathrm{N}$ fertilizer (Wells and Turner, 1984). LCC developed in Japan is used to measure the green color intensity of rice leaves (Furuya, 1987). Need based $N$ application would result in greater agronomic efficiency of $\mathrm{N}$ fertilizer than the commonly practiced method (Hussain et al., 2000). However, there is an ample need to find out the relative efficiency of different application methods of $\mathrm{N}$ fertilizer on the performance of rice crops (Hasanuzzaman et al., 2009).

Zhang (2007) proposed strategies for developing Green Super Rice (GSR) to meet the challenges in rice production. In 2010, the Ministry of Science and Technology of China launched a mega project to develop GSR as proposed by Zhang (2007). One main aspect of this project is to decrease $\mathrm{N}$ fertilizer application in rice production through the genetic development of $\mathrm{N}$ efficient varieties. In light of this aim, the present study was undertaken to observe the response of different methods of application of nitrogenous fertilizer on the performance of popular variety BRRI dhan 28 and exotic GSR (Green Super Rice) genotype GSR I Sal Y 1242.

\section{Materials and Methods}

\section{Experimental Site}

The field experiment was carried out at the BRAC Agricultural Research and Development Centre, Gazipur under the agro-ecological zone of Modhupur Tract, AEZ28. Geographically the experimental area is located at $23^{\circ} 58^{\prime} \mathrm{N}$ latitude and $90^{\circ} 23^{\prime} \mathrm{E}$ longitude at an altitude of $18 \mathrm{~m}$ above the sea level. The experimental site belongs to the Grey Terrace Soils under Chhiiata Series containing $19.23 \%, 78.84 \%$ and $1.93 \%$ of sand, silt and clay, respectively. The soil layer is $0-20 \mathrm{~cm}$ deep; having $\mathrm{pH}$ 6.42 (Sorensen, 1909); 1.68\% organic matter (Walkley and Black, 1934); 0.086\% total N (Yoshida et al., 1976); $15.20 \mu \mathrm{g} \mathrm{g}^{-1}$ soil available P (Olsen et al., 1954); $14.89 \mu \mathrm{g}$ $\mathrm{g}^{-1}$ soil available $\mathrm{S}$ (Calcium dihydrogen phosphate extraction method) and $0.116 \mathrm{meq} 100 \mathrm{~g}^{-1}$ soil exchangeable K (Jackson, 1973). The information regarding rainfall pattern, temperature fluctuations and sunshine hour's data collected from the meteorological station of BRRI, plant physiology division that located near to the experimental site during 2012/2013 and 2013/2014 rice growing seasons, are presented in Figure 1.

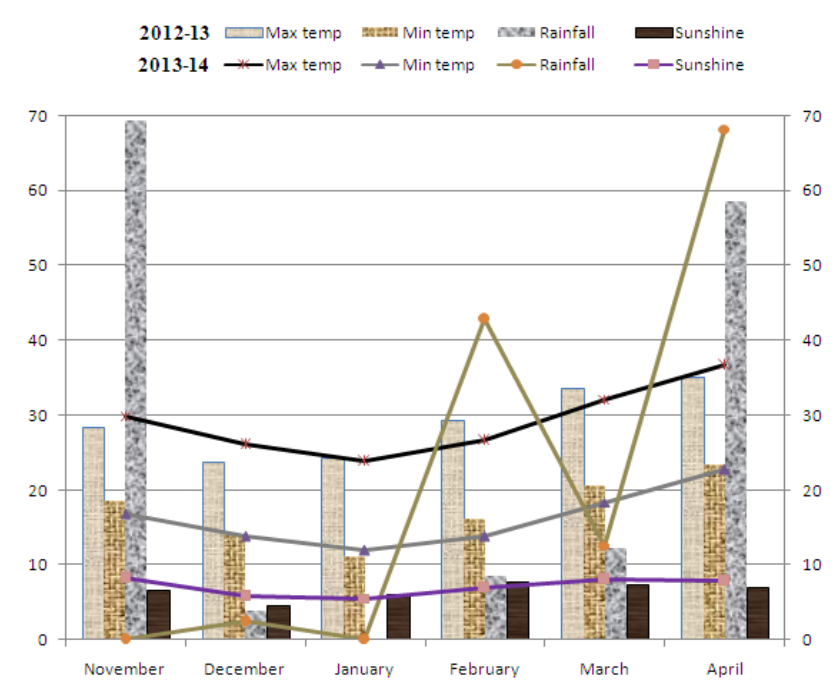

Figure 1 Rainfall, maximum and minimum temperatures and sunshine hours recorded at study area over two years during the crop period

\section{Experimental Design and Procedure}

The experiment was conducted with a view to find out the performance of Boro rice in response to different application methods of urea fertilizer during 2012/2013 and 2013/2014 growing seasons. The experiment was arranged in a split-plot design with three replications. The experimental treatments comprised with four urea application methods $\left(\mathrm{T}_{1}=220 \mathrm{~kg} \mathrm{ha}^{-1} \mathrm{PU}\right.$ at three equal splits, $1 / 3$ at final land preparation $+1 / 3$ at maximum tillering stage $+1 / 3$ at PI (Panicle initiation) stage, $\mathrm{T}_{2}=$ $2 \%$ foliar spray @ $80 \mathrm{~kg} \mathrm{ha}^{-1}$ from 10 DAT at 7 days interval up to flowering, $\mathrm{T}_{3}=75 \mathrm{~kg} \mathrm{~N} \mathrm{ha}^{-1} \mathrm{USG}(2.7 \mathrm{~g})$ at $15 \mathrm{DAT}, \mathrm{T}_{4}=\mathrm{LCC}$ based urea @ $67.5 \mathrm{~kg} \mathrm{ha}^{-1}$ at $21 \mathrm{DAT}$ up to flowering as and when necessary) were used as sub plot and two Boro genotypes $\mathrm{V}_{1}=$ GSR I Sal Y 1242 (exotic GSR inbred), $\mathrm{V}_{2}=$ BRRI dhan28 (popular inbred) were used as main plot. Phosphate $(\mathrm{P})$, potash $(\mathrm{K})$, sulphur (S) and zinc (Zn) @ 130, 120, 70, $10 \mathrm{~kg} \mathrm{ha}^{-1}$ in the form of triple super phosphate (TSP), muriate of potash (MoP), gypsum, and zinc sulphate, respectively were used as basal. Nitrogenous fertilizers were applied as per treatment. The USG weighing $2.7 \mathrm{~g}$ size each was placed manually in the root zone at $5-10 \mathrm{~cm}$ soil depth at 15 days after transplanting (DAT) in the center of four hills of two adjacent rows @ 1 granule in one spot to supply $75 \mathrm{~kg} \mathrm{~N} \mathrm{ha}^{-1}$ as per Adhunik Dhaner Chash (BRRI, 2008). After the establishment of seedlings with proper care in seed bed; 31 days old seedlings were transplanted with two seedlings in each hill, maintaining the spacing with $20 \mathrm{~cm} \times 20 \mathrm{~cm}$ on the well puddle plots. Standard crop production management practices for weeding, irrigation, crop protection operations were followed as and when required until the crop was mature.

\section{Measurement of Parameters}

Five hills (excluding border hills) from each sub-plot were selected and tagged after transplanting for taking growth parameters data at various stages and then at physiological maturity stage the hills were uprooted, cleaned, and standard data collection procedure maintained for taking yield component's data. Morphological datas were collected for qualitative and 
quantitative characters at the appropriate growth stage of rice plant following the description for Oryza sativa L. (IRRI, 2002). The characters that were evaluated are plant height $(\mathrm{cm})$, number of tillers $\mathrm{m}^{-2}$, dry weight hill ${ }^{-1}(\mathrm{~g}), \mathrm{N}$ content $(\%)$ hill $^{-1}$, panicles no. $\mathrm{m}^{-2}$, panicle length $(\mathrm{cm})$, filled grains panicle ${ }^{-1}$, unfilled grains panicle ${ }^{-1}, 1000$ grain weight $(\mathrm{g})$, grain yield (ton $\mathrm{ha}^{-1}$ ) and harvest index $(\%)$ were recorded. An area of $5 \mathrm{~m}^{2}$ was harvested from the centre of each plot and the plants were threshed; cleaned, sun dried, weighted and adjusted at $14 \%$ moisture content to estimate the grain yield. The grain moisture content was estimated with a digital moisture meter (GMK 303RS, Korea). The grain and straw yield (at 14\% moisture content) on the sun dry weight basis were reported in $\mathrm{t} \mathrm{ha}^{-1}$. The randomly selected five plant samples from each sub-plot were separated into different plant components and then oven dry at $80^{\circ} \mathrm{c}$ temperature to a constant weight for measuring total dry weight hill ${ }^{-1}$ at different growth stages. Nitrogen content (root, stem, leaf and grain) from three plant samples of each sub-plot were determined by the micro Kjeldahl method (Yoshida et al., 1976). Harvest index (\%) was calculated using the following formula: Grain yield/Biological yield $\times 100$.

\section{Statistical Analysis}

The recorded data were analyzed statistically using the statistical computer package program MSTAT-C (Russell, 1986) and the mean values separated using least significant differences (LSD) test (Gomez and Gomez, 1984) at $5 \%$ level of significance.

\section{Results and Discussion}

\section{Effect on Plant Height}

Genotypes exerted a significant influence on plant height in 40 DAT and 60 DAT but later on a nonsignificant response was found in $50 \%$ flowering and at harvest (Table 1). Results showed that $\mathrm{V}_{2}$ had the higher plant height $(44.34$ and $72.30 \mathrm{~cm})$ compare to $\mathrm{V}_{1}(42.41$ and $59.37 \mathrm{~cm}$ ) at 40 DAT and 60 DAT, respectively. These results also in agreement with Bisne et al. (2006) who stated that plant height significantly differed among different varieties.

Plant height was significantly influenced by different urea fertilizer application methods at 60 DAT and maturity stage, but non-significant at 40 DAT and $50 \%$ flowering (Table 1). The tallest plant at 60 DAT (69.14 $\mathrm{cm})$ and at harvest $(103.48 \mathrm{~cm})$ was recorded by $\mathrm{T}_{3}$, which was statistically identical with $\mathrm{T}_{4}$ at harvest. The significant shortest plant (63.96 and $98.95 \mathrm{~cm})$ and $(65.60$ and $97.78 \mathrm{~cm}$ ) was observed in $T_{1}$ and $T_{2}$ treatment at 60 DAT and at harvest, respectively. The result under the present study was similar with the findings of Rahman (2003), Alam (2002) and Vijaya and Subbaiah (1997). Sathiya and Ramesh (2009) also stated that application of nitrogen in split according to the crop needs based on LCC was the reason for better rice growth parameter.

The interaction effect of genotype and different urea fertilizer application methods significantly influenced the plant height at different growth stages of Boro rice (Table $2)$. Results indicated that the longest plant $(46.17 \mathrm{~cm}$, $76.08 \mathrm{~cm}, 101.30 \mathrm{~cm}$, and $106.60 \mathrm{~cm}$ at $40 \mathrm{DAT}, 60$ DAT, $50 \%$ flowering, and at harvest, respectively) was with $\mathrm{V}_{2} \mathrm{~T}_{3}$. On the other hand, $\mathrm{V}_{2} \mathrm{~T}_{2}$ showed the lowest plant height $(93.20 \mathrm{~cm}$ and $96.96 \mathrm{~cm}$ at $50 \%$ flowering and at harvest, respectively) which was statistically similar to $\mathrm{V}_{2} \mathrm{~T}_{1}$ at $50 \%$ flowering and at harvest but with $\mathrm{V}_{1} \mathrm{~T}_{1}$ and $\mathrm{V}_{1} \mathrm{~T}_{2}$ only at maturity stage. The results obtained from all other treatments at different growth stages on plant height gave statistically significant results.

\section{Effect on Tillering Pattern}

The genotypes had no significant influence on the number of tillers $\mathrm{m}^{-2}$ in 40 DAT, 60 DAT, and at $50 \%$ flowering, respectively but significant only at harvest (Table 3). Comparing tiller producing capacity of tillers $\mathrm{m}^{-2}$ between the two genotypes at harvest, $\mathrm{V}_{1}$ showed the lower number of tillers $\mathrm{m}^{-2}$ (303.12) than $\mathrm{V}_{2}$ (318.95).

Variation in the number of tillers $\mathrm{m}^{-2}$ was statistically significant for different urea fertilizer application methods throughout the growth period of Boro rice (Table 3 ). The highest number of tillers $\mathrm{m}^{-2}$ was recorded by $\mathrm{T}_{3}(290.83$ and 349.06 at 40 and 60 DAT, respectively) but later on the highest tillers $\mathrm{m}^{-2}$ was recorded from $\mathrm{T}_{4}$ at $50 \%$ flowering and at harvest. Similar results observed by Hasanuzzaman et al. (2009) who reported that deep placement of USG @ $75 \mathrm{~kg} \mathrm{~N} \mathrm{ha}^{-1}$ showed the highest number of tillers. This results also in agreement with the findings of Rahman (2003) and Alam (2002). The results obtained from $\mathrm{T}_{2}$ showed the lowest number of tillers $\mathrm{m}^{-2}$ (308.75 and 282.08) which was closely followed by $\mathrm{T}_{1}$ at $50 \%$ flowering and at harvest, respectively.

Table 1 Effect of variety and urea fertilizer application methods on plant height of Boro rice

\begin{tabular}{|c|c|c|c|c|}
\hline \multirow{2}{*}{ Treatment } & \multicolumn{4}{|c|}{ Plant height $(\mathrm{cm})$} \\
\hline & $40 \mathrm{DAT}$ & $60 \mathrm{DAT}$ & At $50 \%$ flowering & At harvest \\
\hline \multicolumn{5}{|c|}{ Effect of genotype } \\
\hline $\mathrm{V}_{1}$ & $42.41^{\mathrm{b}}$ & $59.37^{\mathrm{b}}$ & 97.63 & 100.14 \\
\hline $\mathrm{V}_{2}$ & $44.34^{\mathrm{a}}$ & $72.30^{\mathrm{a}}$ & 97.24 & 101.50 \\
\hline $\operatorname{LSD}_{(0.05)}$ & 1.72 & 2.78 & NS & NS \\
\hline \multicolumn{5}{|c|}{ Effect of different methods of Urea application } \\
\hline $\mathrm{T}_{1}$ & 42.33 & $63.96^{\mathrm{b}}$ & 96.51 & $98.95^{\mathrm{b}}$ \\
\hline $\mathrm{T}_{2}$ & 43.76 & $65.60^{\mathrm{b}}$ & 96.55 & $97.78^{\mathrm{b}}$ \\
\hline $\mathrm{T}_{3}$ & 44.96 & $69.14^{\mathrm{a}}$ & 99.30 & $103.48^{a}$ \\
\hline $\mathrm{T}_{4}$ & 42.45 & $64.64^{\mathrm{b}}$ & 97.38 & $103.06^{\mathrm{a}}$ \\
\hline $\operatorname{LSD}_{(0.05)}$ & NS & 3.273 & NS & 2.987 \\
\hline $\mathrm{CV}(\%)$ & 6.46 & 3.95 & 2.46 & 2.36 \\
\hline
\end{tabular}


Table 2 Combined effect of variety and urea fertilizer application methods on plant height of Boro rice

\begin{tabular}{|c|c|c|c|c|}
\hline \multirow{2}{*}{ Treatment } & \multicolumn{4}{|c|}{ Plant height $(\mathrm{cm})$} \\
\hline & $40 \mathrm{DAT}$ & $60 \mathrm{DAT}$ & At $50 \%$ flowering & At harvest \\
\hline \multicolumn{5}{|c|}{ Combined effect of genotype and different methods of Urea application } \\
\hline $\mathrm{V}_{1} \mathrm{~T}_{1}$ & $41.90^{\mathrm{ab}}$ & $58.43^{\mathrm{c}}$ & $97.63^{\mathrm{abc}}$ & $99.83^{\mathrm{cd}}$ \\
\hline $\mathrm{V}_{1} \mathrm{~T}_{2}$ & $43.03^{\mathrm{ab}}$ & $59.25^{\mathrm{c}}$ & $99.90^{\mathrm{ab}}$ & $98.60^{\mathrm{cd}}$ \\
\hline $\mathrm{V}_{1} \mathrm{~T}_{3}$ & $43.77^{\mathrm{ab}}$ & $62.19^{c}$ & $97.30^{\mathrm{a}-\mathrm{d}}$ & $100.36^{\mathrm{bcd}}$ \\
\hline $\mathrm{V}_{1} \mathrm{~T}_{4}$ & $40.97^{\mathrm{b}}$ & $57.62^{\mathrm{c}}$ & $95.70^{\mathrm{bcd}}$ & $101.76^{\mathrm{bc}}$ \\
\hline $\mathrm{V}_{2} \mathrm{~T}_{1}$ & $42.77^{\mathrm{ab}}$ & $69.49^{\mathrm{b}}$ & $95.40^{\mathrm{cd}}$ & $98.06^{\mathrm{cd}}$ \\
\hline $\mathrm{V}_{2} \mathrm{~T}_{2}$ & $44.50^{\mathrm{ab}}$ & $71.95^{\mathrm{ab}}$ & $93.20^{\mathrm{d}}$ & $96.96^{\mathrm{d}}$ \\
\hline $\mathrm{V}_{2} \mathrm{~T}_{3}$ & $46.17^{\mathrm{a}}$ & $76.08^{a}$ & $101.30^{\mathrm{a}}$ & $106.60^{\mathrm{a}}$ \\
\hline $\mathrm{V}_{2} \mathrm{~T}_{4}$ & $43.93^{\mathrm{ab}}$ & $71.66^{\mathrm{ab}}$ & $99.06^{\mathrm{abc}}$ & $104.36^{\mathrm{ab}}$ \\
\hline $\operatorname{LSD}_{(0.05)}$ & 4.983 & 4.629 & 4.258 & 4.225 \\
\hline $\mathrm{CV}(\%)$ & 6.46 & 3.95 & 2.46 & 2.36 \\
\hline
\end{tabular}

Table 3 Effect of variety and urea fertilizer application methods on number of tillers $\mathrm{m}^{-2}$ of Boro rice

\begin{tabular}{|c|c|c|c|c|}
\hline \multirow{2}{*}{ Treatment } & \multicolumn{4}{|c|}{ Number of tillers $\mathrm{m}^{-2}$} \\
\hline & $40 \mathrm{DAT}$ & $60 \mathrm{DAT}$ & At $50 \%$ flowering & At harvest \\
\hline \multicolumn{5}{|c|}{ Effect of genotype } \\
\hline $\mathrm{V}_{1}$ & 234.37 & 311.46 & 336.04 & $303.12^{\mathrm{b}}$ \\
\hline $\mathrm{V}_{2}$ & 262.70 & 319.74 & 368.12 & $318.95^{\mathrm{a}}$ \\
\hline $\operatorname{LSD}_{(0.05)}$ & NS & NS & NS & 6.46 \\
\hline \multicolumn{5}{|c|}{ Effect of different methods of Urea application } \\
\hline $\mathrm{T}_{1}$ & $237.91^{\mathrm{b}}$ & $305.31^{\mathrm{ab}}$ & $341.25^{\mathrm{bc}}$ & $303.75^{\mathrm{bc}}$ \\
\hline $\mathrm{T}_{2}$ & $232.91^{\mathrm{b}}$ & $304.69^{\mathrm{ab}}$ & $308.75^{\mathrm{c}}$ & $282.08^{\mathrm{c}}$ \\
\hline $\mathrm{T}_{3}$ & $290.83^{a}$ & $349.06^{\mathrm{a}}$ & $373.75^{\mathrm{ab}}$ & $325.83^{\mathrm{ab}}$ \\
\hline $\mathrm{T}_{4}$ & $232.50^{\mathrm{b}}$ & $303.33^{b}$ & $384.58^{\mathrm{a}}$ & $332.50^{\mathrm{a}}$ \\
\hline $\operatorname{LSD}_{(0.05)}$ & 24.64 & 44.86 & 32.53 & 25.08 \\
\hline $\mathrm{CV}(\%)$ & 7.88 & 11.30 & 7.34 & 6.41 \\
\hline
\end{tabular}

Table 4 Combined effect of variety and urea fertilizer application methods on number of tillers $\mathrm{m}^{-2}$ of Boro rice

\begin{tabular}{|c|c|c|c|c|}
\hline \multirow{2}{*}{ Treatment } & \multicolumn{4}{|c|}{ Number of tillers $\mathrm{m}^{-2}$} \\
\hline & $40 \mathrm{DAT}$ & $60 \mathrm{DAT}$ & At $50 \%$ flowering & At harvest \\
\hline \multicolumn{5}{|c|}{ Combined effect of genotype and different methods of Urea application } \\
\hline $\mathrm{V}_{1} \mathrm{~T}_{1}$ & $223.33^{\mathrm{cd}}$ & $294.79^{\mathrm{b}}$ & $321.66^{\mathrm{de}}$ & $287.50^{\mathrm{cd}}$ \\
\hline $\mathrm{V}_{1} \mathrm{~T}_{2}$ & $215.83^{\mathrm{d}}$ & $291.04^{\mathrm{b}}$ & $311.66^{\mathrm{e}}$ & $268.33^{\mathrm{d}}$ \\
\hline $\mathrm{V}_{1} \mathrm{~T}_{3}$ & $276.66^{\mathrm{ab}}$ & $338.96^{\mathrm{ab}}$ & $339.16^{\text {cde }}$ & $305.00^{\mathrm{c}}$ \\
\hline $\mathrm{V}_{1} \mathrm{~T}_{4}$ & $221.66^{\mathrm{cd}}$ & $321.04^{\mathrm{ab}}$ & $371.66^{\mathrm{abc}}$ & $351.66^{\mathrm{a}}$ \\
\hline $\mathrm{V}_{2} \mathrm{~T}_{1}$ & $252.50^{\mathrm{bc}}$ & $315.83^{\mathrm{ab}}$ & $360.83^{\text {bcd }}$ & $320.00^{\mathrm{abc}}$ \\
\hline $\mathrm{V}_{2} \mathrm{~T}_{2}$ & $250.00^{\mathrm{bcd}}$ & $318.33^{\mathrm{ab}}$ & $305.83^{\mathrm{e}}$ & $295.83^{\mathrm{cd}}$ \\
\hline $\mathrm{V}_{2} \mathrm{~T}_{3}$ & $305.00^{\mathrm{a}}$ & $359.17^{\mathrm{a}}$ & $408.33^{\mathrm{a}}$ & $346.66^{\mathrm{ab}}$ \\
\hline $\mathrm{V}_{2} \mathrm{~T}_{4}$ & $243.33^{\mathrm{bcd}}$ & $285.62^{\mathrm{b}}$ & $397.50^{\mathrm{ab}}$ & $313.33^{b c}$ \\
\hline $\operatorname{LSD}_{(0.05)}$ & 34.85 & 63.44 & 46.01 & 35.47 \\
\hline $\mathrm{CV}(\%)$ & 7.88 & 11.30 & 7.34 & 6.41 \\
\hline
\end{tabular}

Table 5 Dry weight hill $^{-1}$ of rice as influenced by variety and different urea fertilizer application methods

\begin{tabular}{|c|c|c|c|c|}
\hline \multirow{2}{*}{ Treatment } & \multicolumn{4}{|c|}{ Dry weight hill-1 $(\mathrm{g})$} \\
\hline & 40 DAT & $60 \mathrm{DAT}$ & At $50 \%$ flowering & At harvest \\
\hline \multicolumn{5}{|c|}{ Effect of genotype } \\
\hline $\mathrm{V}_{1}$ & 40.55 & 48.76 & 68.31 & 84.83 \\
\hline $\mathrm{V}_{2}$ & 45.54 & 53.88 & 65.00 & 77.75 \\
\hline $\operatorname{LSD}_{(0.05)}$ & NS & NS & NS & NS \\
\hline \multicolumn{5}{|c|}{ Effect of different methods of Urea application } \\
\hline $\mathrm{T}_{1}$ & $35.90^{c}$ & $43.51^{\mathrm{b}}$ & $59.99^{\mathrm{b}}$ & $76.18^{\mathrm{b}}$ \\
\hline $\mathrm{T}_{2}$ & $38.65^{\mathrm{bc}}$ & $47.23^{\mathrm{b}}$ & $67.42^{\mathrm{a}}$ & $80.45^{\mathrm{b}}$ \\
\hline $\mathrm{T}_{3}$ & $47.21^{\mathrm{ab}}$ & $55.35^{\mathrm{ab}}$ & $67.38^{\mathrm{a}}$ & $80.83^{\mathrm{ab}}$ \\
\hline $\mathrm{T}_{4}$ & $50.42^{\mathrm{a}}$ & $59.21^{\mathrm{a}}$ & $71.82^{\mathrm{a}}$ & $87.71^{\mathrm{a}}$ \\
\hline $\operatorname{LSD}_{(0.05)}$ & 10.940 & 11.850 & 7.283 & 9.900 \\
\hline $\mathrm{CV}(\%)$ & 20.19 & 18.36 & 8.69 & 6.85 \\
\hline
\end{tabular}


The combined effect of genotype and different methods of urea application significantly influenced the number of tillers $\mathrm{m}^{-2}$ at different growth stages of the two genotypes of Boro rice (Table 4). Results indicated that the highest number of tillers $\mathrm{m}^{-2}(305.00,359.17$, and 408.33 at 40 DAT, 60 DAT, and at $50 \%$ flowering, respectively) was recorded with $\mathrm{V}_{2} \mathrm{~T}_{3}$ which was closely followed by $\mathrm{V}_{1} \mathrm{~T}_{3}$ at 40 and $60 \mathrm{DAT}$; with $\mathrm{V}_{1} \mathrm{~T}_{4}, \mathrm{~V}_{2} \mathrm{~T}_{1}$, and $\mathrm{V}_{2} \mathrm{~T}_{2}$ at 60 DAT but with $\mathrm{V}_{1} \mathrm{~T}_{4}$ and $\mathrm{V}_{2} \mathrm{~T}_{4}$ at $50 \%$ flowering stage. $V_{1} T_{4}$ which was closely followed by $\mathrm{V}_{2} \mathrm{~T}_{3}$ and $\mathrm{V}_{2} \mathrm{~T}_{1}$ obtained the highest tillers number $\mathrm{m}^{-2}$ (351.66) at harvest. The lowest number of tillers $\mathrm{m}^{-2}$ was recorded from $\mathrm{V}_{1} \mathrm{~T}_{2}(215.83,311.66$, and 268.33 at 40 DAT, 50\% flowering, and at harvest, respectively) which was statistically identical with $\mathrm{V}_{1} \mathrm{~T}_{1}$ at 40 DAT, 50\% flowering, and at harvest, respectively; $\mathrm{V}_{1} \mathrm{~T}_{4}$ and $\mathrm{V}_{2} \mathrm{~T}_{4}$ at 40 DAT but closely related with $\mathrm{V}_{2} \mathrm{~T}_{2}$ at 40 DAT, $50 \%$ flowering, and at harvest, respectively.

\section{Effect on Dry Weight Hill ${ }^{-1}$}

Non-significant variation was observed in terms of dry weight hill-1 for genotypic variation (Table 5).

Different urea fertilizer application methods significantly affect the dry weight hill $^{-1}$ at all growth stages (Table 5). The highest dry weight hill ${ }^{-1}$ was recorded for $\mathrm{T}_{4}(50.42 \mathrm{~g}, 59.21 \mathrm{~g}, 71.82 \mathrm{~g}$, and $87.71 \mathrm{~g}$ at 40 DAT, 60 DAT, 50\% flowering, and at harvest, respectively) which were statistically identical with $\mathrm{T}_{3}$ at all growth stages but similar with $\mathrm{T}_{2}$ at $50 \%$ flowering. The lowest dry weight hill ${ }^{-1}$ was recorded from $\mathrm{T}_{1}(35.90$ g, $43.51 \mathrm{~g}, 59.99 \mathrm{~g}$, and $76.18 \mathrm{~g}$ at 40 DAT, $60 \mathrm{DAT}, 50 \%$ flowering, and at harvest, respectively) which were closely followed by $\mathrm{T}_{2}$ at 40 DAT, 60 DAT, and at harvest, respectively. The results under the present study was similar with the findings of Vijaya and Subbaiah (1997) and Jayanthi et al. (2007).

Variation in dry weight hill $^{-1}$ was statistically significant for the combination of genotype and different urea fertilizer application methods (Table 6). $\mathrm{V}_{2} \mathrm{~T}_{4}$ showed the highest dry weight hill $^{-1}(54.03 \mathrm{~g}, 61.87 \mathrm{~g}$, $73.40 \mathrm{~g}$, and $87.30 \mathrm{~g}$ at $40 \mathrm{DAT}, 60 \mathrm{DAT}, 50 \%$ flowering, and at harvest, respectively) which was closely followed by $V_{1} T_{3}, V_{1} T_{4}$, and $V_{2} T_{2}$ at all growth stages also with $\mathrm{V}_{1} \mathrm{~T}_{1}$ and $\mathrm{V}_{2} \mathrm{~T}_{3}$ except 40 DAT and at harvest, respectively. The results recorded from $\mathrm{V}_{2} \mathrm{~T}_{1}$ showed obtain the lowest dry weight hill-1 $(33.69 \mathrm{~g}, 40.56 \mathrm{~g}, 56.01$ $\mathrm{g}$, and $69.60 \mathrm{~g}$ at $40 \mathrm{DAT}, 60 \mathrm{DAT}, 50 \%$ flowering, and at harvest, respectively) which was similar with $\mathrm{V}_{1} \mathrm{~T}_{2}$ at 40 DAT and 60 DAT; statistically identical with $\mathrm{V}_{2} \mathrm{~T}_{2}$ at all growth stages as well as with $\mathrm{V}_{1} \mathrm{~T}_{1}$ except at the time of harvest. However, $\mathrm{V}_{1} \mathrm{~T}_{3}$ and $\mathrm{V}_{1} \mathrm{~T}_{4}$ showed similar results at all growth stages.

\section{Effect on N Content (\%) Hill $^{-1}$}

Genotypes exerted a significant influence on root $\mathrm{N}$ content $(\%)$ but non-significant in the case of leaf, stem and grain $\mathrm{N}$ content $(\%)$. The highest $\mathrm{N}$ content in root $(0.469 \%)$ was obtained from $\mathrm{V}_{1}$ followed by $\mathrm{V}_{2}$ i.e. $0.449 \% \mathrm{~N}$ (Table7).

Table 6 Dry weight hill $^{-1}$ of rice as influenced by combined effect of variety and different urea fertilizer application methods

\begin{tabular}{|c|c|c|c|c|}
\hline \multirow{2}{*}{ Treatment } & \multicolumn{4}{|c|}{ Dry weight hill-1 $(\mathrm{g})$} \\
\hline & $40 \mathrm{DAT}$ & $60 \mathrm{DAT}$ & At $50 \%$ flowering & At harvest \\
\hline \multicolumn{5}{|c|}{ Combined effect of genotype and different methods of Urea application } \\
\hline $\mathrm{V}_{1} \mathrm{~T}_{1}$ & $38.11^{\mathrm{bc}}$ & $46.25^{\mathrm{ab}}$ & $63.98^{\mathrm{ab}}$ & $82.76^{\mathrm{ab}}$ \\
\hline $\mathrm{V}_{1} \mathrm{~T}_{2}$ & $34.88^{c}$ & $42.22^{\mathrm{b}}$ & $68.75^{\mathrm{a}}$ & $82.00^{\mathrm{ab}}$ \\
\hline $\mathrm{V}_{1} \mathrm{~T}_{3}$ & $42.43^{\mathrm{abc}}$ & $50.03^{\mathrm{ab}}$ & $70.25^{\mathrm{a}}$ & $86.43^{\mathrm{a}}$ \\
\hline $\mathrm{V}_{1} \mathrm{~T}_{4}$ & $46.80^{\mathrm{abc}}$ & $56.56^{\mathrm{ab}}$ & $70.25^{\mathrm{a}}$ & $88.13^{\mathrm{a}}$ \\
\hline $\mathrm{V}_{2} \mathrm{~T}_{1}$ & $33.69^{c}$ & $40.56^{\mathrm{b}}$ & $56.01^{\mathrm{b}}$ & $69.60^{c}$ \\
\hline $\mathrm{V}_{2} \mathrm{~T}_{2}$ & $42.43^{\mathrm{abc}}$ & $52.24^{\mathrm{ab}}$ & $66.08^{\mathrm{ab}}$ & $78.90^{\mathrm{abc}}$ \\
\hline $\mathrm{V}_{2} \mathrm{~T}_{3}$ & $52.00^{\mathrm{ab}}$ & $60.66^{\mathrm{a}}$ & $64.51^{\mathrm{ab}}$ & $75.23^{b c}$ \\
\hline $\mathrm{V}_{2} \mathrm{~T}_{4}$ & $54.03^{\mathrm{a}}$ & $61.87^{\mathrm{a}}$ & $73.40^{\mathrm{a}}$ & $87.30^{\mathrm{a}}$ \\
\hline $\operatorname{LSD}_{(0.05)}$ & 15.460 & 16.760 & 10.300 & 7.001 \\
\hline $\mathrm{CV}(\%)$ & 20.19 & 18.36 & 8.69 & 6.85 \\
\hline
\end{tabular}

Table 7 Effect of variety and urea fertilizer application methods on nitrogen content $(\%)$ of Boro rice at harvest

\begin{tabular}{|c|c|c|c|c|}
\hline \multirow{2}{*}{ Treatment } & \multicolumn{4}{|c|}{$\mathrm{N}$ content $(\%)$} \\
\hline & Root & Stem & Leaf & Grain \\
\hline \multicolumn{5}{|c|}{ Effect of genotype } \\
\hline $\mathrm{V}_{1}$ & $0.469^{\mathrm{a}}$ & 0.541 & 1.269 & 1.207 \\
\hline $\mathrm{V}_{2}$ & $0.449^{\mathrm{b}}$ & 0.627 & 1.382 & 1.254 \\
\hline $\operatorname{LSD}_{(0.05)}$ & 0.01 & NS & NS & NS \\
\hline \multicolumn{5}{|c|}{ Effect of different methods of Urea application } \\
\hline $\mathrm{T}_{1}$ & $0.467^{\mathrm{b}}$ & $0.607^{\mathrm{ab}}$ & $1.397^{\mathrm{a}}$ & $1.393^{\mathrm{a}}$ \\
\hline $\mathrm{T}_{2}$ & $0.408^{c}$ & $0.562^{\mathrm{bc}}$ & $1.210^{\mathrm{b}}$ & $1.182^{\mathrm{b}}$ \\
\hline $\mathrm{T}_{3}$ & $0.407^{\mathrm{c}}$ & $0.527^{\mathrm{c}}$ & $1.218^{\mathrm{b}}$ & $1.160^{\mathrm{b}}$ \\
\hline $\mathrm{T}_{4}$ & $0.555^{\mathrm{a}}$ & $0.640^{\mathrm{a}}$ & $1.447^{\mathrm{a}}$ & $1.187^{b}$ \\
\hline $\operatorname{LSD}_{(0.05)}$ & 0.056 & 0.056 & 0.112 & 0.105 \\
\hline $\mathrm{CV}(\%)$ & 9.91 & 7.98 & 6.69 & 6.93 \\
\hline
\end{tabular}


Table 8 Combined effect of variety and urea fertilizer application methods on nitrogen content (\%) of Boro rice at harvest

\begin{tabular}{|c|c|c|c|c|}
\hline \multirow{2}{*}{ Treatment } & \multicolumn{4}{|c|}{$\mathrm{N}$ content $(\%)$} \\
\hline & Root & Stem & Leaf & Grain \\
\hline \multicolumn{5}{|c|}{ Combined effect of genotype and different methods of Urea application } \\
\hline $\mathrm{V}_{1} \mathrm{~T}_{1}$ & $0.440^{\mathrm{cd}}$ & $0.540^{\text {cde }}$ & $1.323^{\mathrm{bcd}}$ & $1.387^{\mathrm{ab}}$ \\
\hline $\mathrm{V}_{1} \mathrm{~T}_{2}$ & $0.477^{\mathrm{bc}}$ & $0.473^{\mathrm{e}}$ & $1.120^{\mathrm{e}}$ & $1.130^{\mathrm{c}}$ \\
\hline $\mathrm{V}_{1} \mathrm{~T}_{3}$ & $0.377^{\text {de }}$ & $0.560^{\mathrm{cd}}$ & $1.217^{\mathrm{de}}$ & $1.137^{\mathrm{c}}$ \\
\hline $\mathrm{V}_{1} \mathrm{~T}_{4}$ & $0.583^{\mathrm{a}}$ & $0.590^{\mathrm{bc}}$ & $1.417^{\mathrm{abc}}$ & $1.173^{\mathrm{c}}$ \\
\hline $\mathrm{V}_{2} \mathrm{~T}_{1}$ & $0.493^{\mathrm{bc}}$ & $0.673^{\mathrm{a}}$ & $1.470^{\mathrm{ab}}$ & $1.400^{\mathrm{a}}$ \\
\hline $\mathrm{V}_{2} \mathrm{~T}_{2}$ & $0.340^{\mathrm{e}}$ & $0.650^{\mathrm{ab}}$ & $1.300^{\mathrm{cd}}$ & $1.243^{\mathrm{bc}}$ \\
\hline$V_{2} T_{3}$ & $0.437^{\mathrm{cd}}$ & $0.493^{\mathrm{de}}$ & $1.220^{\mathrm{de}}$ & $1.183^{\mathrm{c}}$ \\
\hline $\mathrm{V}_{2} \mathrm{~T}_{4}$ & $0.527^{\mathrm{ab}}$ & $0.690^{\mathrm{a}}$ & $1.537^{\mathrm{a}}$ & $1.190^{\mathrm{c}}$ \\
\hline $\operatorname{LSD}_{(0.05)}$ & 0.079 & 0.079 & 0.159 & 0.148 \\
\hline $\mathrm{CV}(\%)$ & 9.91 & 7.98 & 6.69 & 6.93 \\
\hline
\end{tabular}

Table 9 Effect of variety and urea fertilizer application methods on yield, yield components and harvest index (\%) of Boro rice

\begin{tabular}{|c|c|c|c|c|c|c|c|}
\hline Treatment & PN & PL & FGP & UGP & GW & GY & $\mathrm{HI}$ \\
\hline \multicolumn{8}{|c|}{ Effect of genotype } \\
\hline $\mathrm{V}_{1}$ & 295.2 & 22.81 & 98.88 & 51.25 & $19.91^{\mathrm{b}}$ & $6.87^{\mathrm{a}}$ & 48.59 \\
\hline $\mathrm{V}_{2}$ & 306.25 & 22.79 & 82.51 & 44.06 & $20.48^{\mathrm{a}}$ & $6.31^{\mathrm{b}}$ & 50.97 \\
\hline $\operatorname{LSD}_{(0.05)}$ & NS & NS & NS & NS & 0.380 & 0.38 & NS \\
\hline \multicolumn{8}{|c|}{ Effect of different methods of Urea application } \\
\hline $\mathrm{T}_{1}$ & $289.58^{b}$ & $22.86^{\mathrm{ab}}$ & $94.59^{\mathrm{ab}}$ & $45.65^{\mathrm{bc}}$ & $19.77^{\mathrm{c}}$ & $6.48^{\mathrm{b}}$ & $49.51^{\mathrm{ab}}$ \\
\hline $\mathrm{T}_{2}$ & $278.33^{b}$ & $22.69^{\mathrm{ab}}$ & $97.23^{\mathrm{a}}$ & $42.96^{\mathrm{c}}$ & $20.22^{\mathrm{b}}$ & $6.21^{\mathrm{c}}$ & $48.39^{\mathrm{b}}$ \\
\hline $\mathrm{T}_{3}$ & $319.16^{\mathrm{a}}$ & $22.27^{\mathrm{b}}$ & $87.98^{\mathrm{ab}}$ & $53.05^{\mathrm{a}}$ & $20.21^{\mathrm{b}}$ & $6.62^{b}$ & $50.53^{\mathrm{a}}$ \\
\hline $\mathrm{T}_{4}$ & $315.83^{\mathrm{a}}$ & $23.39^{\mathrm{a}}$ & $82.98^{\mathrm{b}}$ & $48.97^{\mathrm{ab}}$ & $20.57^{\mathrm{a}}$ & $7.05^{\mathrm{a}}$ & $50.70^{\mathrm{a}}$ \\
\hline $\operatorname{LSD}_{(0.05)}$ & 22.2 & 0.97 & 12.54 & 5.838 & 0.221 & 0.221 & 1.778 \\
\hline CV (\%) & 5.87 & 3.38 & 10.99 & 9.74 & 0.88 & 2.67 & 5.93 \\
\hline
\end{tabular}

PN: Panicle number $\mathrm{m}^{-2}$, PL: Panicle length (cm), FGP: Filled grain panicle ${ }^{-1}$, UGP: Unfilled grain panicle ${ }^{-1}$, GW: 1000 grain weight (g), GY: Grain yield $\left(\mathrm{t} \mathrm{ha}^{-1}\right)$, HI: Harvest index $(\%)$

Table 10 Combined effect of variety and urea fertilizer application methods on yield, yield components and harvest index $(\%)$ of Boro rice

\begin{tabular}{|c|c|c|c|c|c|c|c|}
\hline Treatment & $\mathrm{PN}$ & PL & FGP & UGP & GW & GY & $\mathrm{HI}$ \\
\hline \multicolumn{8}{|c|}{ Combined effect of genotype and different methods of urea application } \\
\hline $\mathrm{V}_{1} \mathrm{~T}_{1}$ & $281.66^{\mathrm{bc}}$ & $22.44^{\mathrm{ab}}$ & $101.81^{\mathrm{ab}}$ & $46.27^{\mathrm{b}}$ & $19.61^{\mathrm{e}}$ & $6.95^{\mathrm{b}}$ & $49.57^{\mathrm{b}}$ \\
\hline $\mathrm{V}_{1} \mathrm{~T}_{2}$ & $262.50^{\mathrm{c}}$ & $22.88^{\mathrm{ab}}$ & $108.36^{\mathrm{a}}$ & $50.33^{\mathrm{ab}}$ & $19.74^{\mathrm{de}}$ & $6.32^{\mathrm{cd}}$ & $46.73^{c}$ \\
\hline $\mathrm{V}_{1} \mathrm{~T}_{3}$ & $295.83^{b}$ & $22.61^{\mathrm{ab}}$ & $101.27^{\mathrm{ab}}$ & $57.42^{\mathrm{a}}$ & $20.24^{\mathrm{c}}$ & $6.88^{b}$ & $49.20 b^{c}$ \\
\hline $\mathrm{V}_{1} \mathrm{~T}_{4}$ & $340.83^{\mathrm{a}}$ & $23.33^{\mathrm{a}}$ & $84.08^{b c}$ & $51.01^{\mathrm{ab}}$ & $20.07^{\mathrm{c}}$ & $7.32^{\mathrm{a}}$ & $48.86^{\mathrm{bc}}$ \\
\hline $\mathrm{V}_{2} \mathrm{~T}_{1}$ & $297.50^{\mathrm{b}}$ & $23.28^{\mathrm{ab}}$ & $87.37^{\mathrm{bc}}$ & $45.03^{b}$ & $19.93^{\mathrm{cd}}$ & $6.02^{\mathrm{d}}$ & $49.46^{\mathrm{b}}$ \\
\hline $\mathrm{V}_{2} \mathrm{~T}_{2}$ & $294.16^{b}$ & $22.50^{\mathrm{ab}}$ & $86.11^{\mathrm{bc}}$ & $35.59^{c}$ & $20.70^{\mathrm{b}}$ & $6.09^{\mathrm{cd}}$ & $50.05^{\mathrm{ab}}$ \\
\hline $\mathrm{V}_{2} \mathrm{~T}_{3}$ & $342.50^{\mathrm{a}}$ & $21.94^{\mathrm{b}}$ & $74.69^{c}$ & $48.69^{b}$ & $20.21^{\mathrm{c}}$ & $6.36^{c}$ & $52.19^{\mathrm{a}}$ \\
\hline $\mathrm{V}_{2} \mathrm{~T}_{4}$ & $290.83^{b c}$ & $23.44^{\mathrm{a}}$ & $81.88^{c}$ & $46.93^{b}$ & $21.08^{\mathrm{a}}$ & $6.77^{b}$ & $52.20^{\mathrm{a}}$ \\
\hline $\operatorname{LSD}_{(0.05)}$ & 31.4 & 1.372 & 17.73 & 8.257 & 0.313 & 0.313 & 2.514 \\
\hline $\mathrm{CV}(\%)$ & 5.87 & 3.38 & 10.99 & 9.74 & 0.88 & 2.67 & 5.93 \\
\hline
\end{tabular}

The $\mathrm{N}$ content $(\%)$ hill $^{-1}$ varied significantly due to different methods of nitrogen application (Table 7). The highest significant $\mathrm{N}(\%)$ content in root $(0.555 \%)$, stem $(0.640 \%)$, and leaf $(1.477 \%)$ was found in $\mathrm{T}_{4}$. The highest $\mathrm{N}$ content $(\%)$ of grain was measured in $\mathrm{T}_{1}(1.393 \%)$ treatment followed by $\mathrm{T}_{4}(1.187 \%)$ which was statistically similar to $\mathrm{T}_{2}(1.182 \%)$ and $\mathrm{T}_{3}(1.160 \%)$ respectively.

The interaction effect of genotype and different methods of urea application showed significance on $\mathrm{N}$ content $(\%)$ hill $^{-1}$ (Table 8$) . \mathrm{V}_{1} \mathrm{~T}_{4}$ showed the highest $\mathrm{N}$ content in root $(0.583 \%)$ which was statistically similar with $\mathrm{V}_{2} \mathrm{~T}_{4}$. The highest concentration of $\mathrm{N}$ in stem $(0.690 \%)$ and leaf $(1.537 \%)$ was observed in $\mathrm{V}_{2} \mathrm{~T}_{4}$ which were identical to $\mathrm{V}_{2} \mathrm{~T}_{1}$ whereas the lowest content of $\mathrm{N}$ was measured $0.473(\%)$ for stem and $1.120(\%)$ for leaf in $\mathrm{V}_{1} \mathrm{~T}_{2}$. In case of grain, the highest $1.40(\%)$ of $\mathrm{N}$ content was detected in $\mathrm{V}_{2} \mathrm{~T}_{1}$ which was statistically similar to $\mathrm{V}_{1} \mathrm{~T}_{1}(1.387 \%)$. The significant lowest amount of $\mathrm{N}$ in grain was found in $\mathrm{V}_{1} \mathrm{~T}_{2}(1.130 \%), \mathrm{V}_{1} \mathrm{~T}_{3}$ $(1.137 \%), \mathrm{V}_{1} \mathrm{~T}_{4}(1.173 \%)$ and $\mathrm{V}_{2} \mathrm{~T}_{3}(1.183 \%)$. 


\section{Effect on Yield and Yield Attributes}

Genotypic variation had non-significant effect on the panicle no. $\mathrm{m}^{-2}$, panicle length $(\mathrm{cm})$, filled grain panicle ${ }^{-1}$, unfilled grain panicle ${ }^{-1}$, and harvest index (\%) but significant response on 1000-grain weight $(\mathrm{g})$ and grain yield ( $\mathrm{t} \mathrm{ha}^{-1}$ ) (Table 9). Qurashi et al. (2013) also reported non-significant varietal effect on harvest index $(\%)$. $\mathrm{V}_{1}$ obtained statistically lower weight (19.91 g) compare to $\mathrm{V}_{2}$ (20.48 g) but ultimately gained higher production $\left(6.87 \mathrm{t} \mathrm{ha}^{-1}\right)$ than $\mathrm{V}_{2}\left(6.31 \mathrm{t} \mathrm{ha}^{-1}\right)$. These results are in agreement with Chowdhury et al. (1993) who reported difference in 1000-grain weight among the varieties.

Different urea fertilizer application methods showed significant influence on yield and yield attributes of Boro rice (Table 9). The highest panicle no. $\mathrm{m}^{-2}$ (315.83), panicle length $(23.39 \mathrm{~cm})$, unfilled grain panicle ${ }^{-1}(48.97)$, 1000 -grain weight $(20.57 \mathrm{~g})$, grain yield $\left(7.05 \mathrm{t} \mathrm{ha}^{-1}\right)$, and harvest index $(50.70 \%)$ were recorded for $\mathrm{T}_{4}$ which was similar with $\mathrm{T}_{3}$ for panicle no. $\mathrm{m}^{-2}$, filled grain panicle ${ }^{-1}$, unfilled grain panicle ${ }^{-1}$, and harvest index (\%). Krishnakumar and Haefele (2013), Kenchaiah et al. (2000) also got similar results for the higher panicle number, lengthier panicle, and grain yield due to LCC based urea application. Alam et al. (2005); Alam et al. (2009); and Baksh et al. (2009) stated that use of LCC for $\mathrm{N}$ management has consistently increased grain yield and profit in comparison to the farmers' fertilizer practice in Bangladesh. The lowest panicle no. $\mathrm{m}^{-2}$ (278.33), unfilled grain panicle $^{-1}$ (42.96), grain yield $\left(6.21 \mathrm{t} \mathrm{ha}^{-1}\right)$, and harvest index $(48.39 \%)$ were recorded from $\mathrm{T}_{2}$, which was similar with $\mathrm{T}_{1}$ for all yield contributing parameters except 1000 -grain weight $(19.77 \mathrm{~g})$ and grain yield (6.48 $\mathrm{t}$ $\mathrm{ha}^{-1}$ ).

Combination of genotype and different urea fertilizer application methods significantly influenced the yield and yield contributing characters of Boro rice (Table 10). Combinations of $\mathrm{V}_{1} \mathrm{~T}_{4}$ and $\mathrm{V}_{2} \mathrm{~T}_{3} ; \mathrm{V}_{1} \mathrm{~T}_{4}$ and $\mathrm{V}_{2} \mathrm{~T}_{4} ; \mathrm{V}_{2} \mathrm{~T}_{3}$ and $\mathrm{V}_{2} \mathrm{~T}_{4}$ showed the highest panicle no. $\mathrm{m}^{-2}$, panicle length, and harvest index (\%), respectively. The highest filled grain panicle ${ }^{-1}(108.36)$, unfilled grain panicle ${ }^{-1}$ (57.42), and 1000-grain weight (21.08) were gained by $\mathrm{V}_{1} \mathrm{~T}_{2}, \mathrm{~V}_{1} \mathrm{~T}_{3}$, and $\mathrm{V}_{2} \mathrm{~T}_{4}$, respectively. The lowest panicle no. $\mathrm{m}^{-2}$ (262.50), filled grain panicle ${ }^{-1}$ (74.69 and 81.88), unfilled grain panicle ${ }^{-1}$ (35.59), 1000-grain weight (19.61 $\mathrm{g})$, and harvest index $(46.73 \%)$ were recorded for the combinations of $\mathrm{V}_{1} \mathrm{~T}_{2} ; \mathrm{V}_{2} \mathrm{~T}_{3}$ and $\mathrm{V}_{2} \mathrm{~T}_{4} ; \mathrm{V}_{2} \mathrm{~T}_{2} ; \mathrm{V}_{1} \mathrm{~T}_{1} ; \mathrm{V}_{1} \mathrm{~T}_{2}$, respectively. The combination of $\mathrm{V}_{1} \mathrm{~T}_{4}$ gave the highest grain yield $\left(7.32 \mathrm{t} \mathrm{ha}^{-1}\right)$ whereas $\mathrm{V}_{2} \mathrm{~T}_{1}$ produced the lowest (6.02 $\left.\mathrm{t} \mathrm{ha}^{-1}\right)$.

\section{Conclusions}

According to the result of the experiment, it can be concluded that the performance of exotic inbred GSR I Sal Y 1242 was better than popular inbred BRRI dhan28 during the Boro season in aspect of yield. Among the different application methods of urea fertilizer, LCC based urea $\mathrm{T}_{4}$ gave the best result. Therefore, it is suggested to cultivate GSR I Sal Y 1242 with LCC based urea application method which was appeared as a promising practice in Boro rice cultivation. However, study should be conducted more regarding these different methods of urea application in different locations with a different soil types for more intensive knowledge.

\section{References}

AIS. 2008. Agriculture Information Service, Krishi Diary, Ministry of Agriculture, Government of the People's Republic of Bangladesh.

Alam BMR. 2002. Effect of different level of urea super granule on the growth and yield of three varieties of boro rice. MS (Ag.) Thesis, Department of Agronomy, Bangladesh Agricultural University, Mymensingh.

Alam MM, Ladha JK, Rahaman KS, Foyjunnessa HR, Khan AH, Buresh RJ. 2005. Leaf Color Chart for Managing Nitrogen Fertilizer in Lowland Rice in Bangladesh. Agron J. 97: 949-959.

Alam MM, Sikder MAA, Islam MS, Kumar V, Ladha JK. 2009. Integrated Crop Management: A Potential Agronomic Technique for Increased Productivity and Profit of Rice Cultivation in Bangladesh, 4th World Congress on Conservation Agriculture, Abstracts, New Delhi, 4-7 February 2009. pp. 106.

Baksh EME, Erenstein O, Page SLG. 2009. Livelihood Improvement through Resource Conserving Technologies in the Lower Gangetic Plains of Northern Bangladesh, 4th World Congress on Conservation Agriculture, Abstracts, New Delhi, 4-7 February 2009. pp. 457.

Balasubramanian V, Morales AC, Cruz RT, Abdulrachman S. 1999. On farm adaptation of knowledge-intensive nitrogen management technologies for rice systems. Nutr. Cycl. Agroecosys. 53: 59-69.

BBS (Bangladesh Bureau of Statistics). 2010. Agriculture crop cutting: Estimation of boro rice 2009-2010. Government of the People's Republic of Bangladesh. Available at: http://www. bbs.gov.bd.

BBS (Bangladesh Bureau of Statistics). 2012. Statistical Year Book of Bangladesh Bureau of Statistics, Statistics and informatics Division, Ministry of Planning, Government of the People's Republic of Bangladesh.

Bijay S, Yadvinder S, Ladha JK, Bronson KF, Balasubramanian V, Jagdeep S, Khind CS. 2002. Chlorophyll Meter and Leaf Color Chart-Based Nitrogen Management for Rice and Wheat in Northwestern India. Agron. J. 94: 821-829.

Bisne R, Motiramani NK, Sarawgi AK. 2006. Identification of high yielding hybrids in rice. Bangladesh J. Agr. Res. 31: 171-174.

BRRI (Bangladesh Rice Research Institute). 2008. Adhunik Dhaner Chash (In Bengali). 14th ed. Bangladesh Rice Research Institure, Gazipur, Bangladesh. pp. 39.

Chowdhury MJU, Sarker AU, Sarkar MAR, Kashem MA. 1993. Effect of variety and number of seedlings hill ${ }^{-1}$ on the yield and its components on late transplanted Aman rice. Bangladesh J. Agr. Sci. 20: 311-316.

Dastan S, Siavoshi M, Zakavi D, Ghanbaria-Malidarreh A, Yadi R, Ghorbannia Delavar E, Nasiri AR. 2012. Application of nitrogen and silicon rates on morphological and chemical lodging related characteristics in rice (Oryza sativa L.) at north of Iran J. Agr. Sci. 4: 12-18.

De Datta SK. 1978. Fertilizer management for efficient use in wet land rice cultivation. International Rice Research Institute, Los Banos, Philippines. pp. 671-701.

Furuya S. 1987. Growth diagnosis of rice plants by means of leaf color. Jpn. Agr. Res. Quart. 20: 147 -154.

Gomez KA, Gomez AA. 1984. Statistical Procedure for Agricultural Research. 2nd ed. John Wiley \& Sons. New York. pp. 207-215.

Hasan MS, Hossain SMA, Salim M, Anwar MP, Azad AKM. 2002. Response of hybrid and inbred rice varieties to the application methods of urea super granules and prilled urea. Pakistan J. Bio. Sci. 5: 746-748. 
Hasanuzzaman M, Nahar K, Alam MM, Hossain MZ, Islam MR. 2009. Response of transplanted rice to different application methods of urea fertilizer. Int. J. Sustain. Agr. 1: $1-5$.

Hatfield JL, Prueger JH. 2004. Nitrogen over-use, under-use and efficiency. In: Proceedings of the 4th International Congress of Crop Science, Brisbane, Queensland, Australia. pp. 52.

Hussain F, Bronson KF, Sing Y, Sing B, Peng S. 2000. Use of Chlorophyll Meter Sufficiency Indices for Nitrogen Management of Irrigated Rice in Asia. Agron. J. 92: 875779.

IRRI (International Rice Research Institute). 2002. Standard evaluation system for rice. International Rice Research Institute, Manila. Available at: http://www.knowledgebank.irri.org/ses/SES.htm.

Jackson ML. 1973. Soil Chemical Analysis. Prentice Hall of India, New Delhi, India.

Jayanthi T, Gali SK, Angadi VV, Chimmad VP. 2007. Effect of leaf colour chart based nitrogen management on growth and yield parameters of rainfed rice. Karnataka J. Agr. Sci. 20: 272-275.

Kenchaiah K, Veeranna HK, Devaraju KM. 2000. LCC and SPAD based $\mathrm{N}$ management under different methods of sowing in rice. In: Abstracts of the 3rd CREMNET Workshop cum meeting in direct seeding and seeders in Rice, Mysore, 18-19 August, 2000. pp. 9.

Krisnnakumar S, Haefele S. 2013. Intregeted nutrient management and LCC based nitrogen management on soil fertility and yield of rice. Acad. J. 8: 2059-2067.

Ladha JK, Fischer KS, Hossain M, Hobbs PR, Hardy B Eds. 2000. Improving the Productivity and Sustainability of RiceWheat Systems of the Indo-Gangetic Plains: A Synthesis of NARS-IRRI Partnership Research Discussion, IRRI, Los Banos. pp. 40.

Millard P, Robinson D. 1990. Effect of the timing and rate of nitrogen-fertilization on the growth and recovery of fertilizer nitrogen within the potato (Solanum tuberosum L.). Crop Fert. Res. 21: 133-140.

Nicoulaud BAL, Bloom AJ. 1996. Absorption and assimilation of foliarly applied urea in tomato. J. Am. Soc. Hortic. Sci. 121: 1117-1121.

Olsen SR, Cole CV, Watanabe FS, Dean LA. 1954. Estimation of available phosphorus by extraction with sodium bicarbonate. US Department of Agriculture, Circular. pp. 939.

Pillai KG, Kundu DK. 1993. Fertilizer Management in Rice. In: Tandon HLS, editor. Fertilizer Management in Food Crops: Fertilizer Development and Consultation Organization, New Delhi. pp. 1-26.
Prashad R, Singh S, Prasad M, Thomas J. 1982. Increased efficiency of fertilizer nitrogen applied to rice through urea super granules. Paper presented at the seminar of Indians Farmers Fertilizers Co-operative Ltd. held at Bangalore during 27-28 May 1982. Indian J. Agr. Sci. 59: 154-156.

Qurashi TA, Salam MA, Jannat M, Rabbani MG. 2013. Evaluation of urea super granule as a source of nitrogen in transplant Aman rice. Prog. Agr. 24: 29-37.

Rahman MA. 2003. Effect of levels of urea super granules and depth of placement on the growth and yield of transplanted Aman rice. MS (Ag.) Thesis, Department of Agronomy, Bangladesh Agricultural University, Mymensingh. pp: 100.

Raut S. 2007. Leaf colour chart based $\mathrm{N}$ management and red edged reflectance of Rice. J. Agr. Phys. 7: 14-19.

Russell DF. 1986. MSTAT-C (A computer based data analysis software). Crop and Soil Science Department, Michigan State University, USA.

Sathiya K, Ramesh T. 2009. Effect of split application of nitrogen on growth and yield aerobic rice. Asian J. Exp. Sci. 23: 303-306.

Sharma AR. 1995. Effect of basal and post flood nitrogen fertilization on performance of rice (oryza sativa L.) under conditions of intermediate deep water and simultaneous flash flooding. Indian J. Agr. Sci. 65: 339-404.

Sørensen SPL. 1909. "Enzymstudien. II: Mitteilung. Über die Messung und die Bedeutung der Wasserstoffionenkoncentration bei enzymatischen Prozessen". Biochem Z. 21: 131-304 (in German).

Vijaya D, Subbaiah SB. 1997. Effect of method of application of granular forms of fertilizer on growth, nutrient uptake and yield of paddy. Ann. Agr. Res. 18: 361-364.

Walkley A, Black TA. 1934. An examination of the digestion method for determining soil organic matter and a proposed modification of chromic acid titration method. Soil Sci. 37: 29-38.

Wells BR, Turner FT. 1984. Nitrogen use in flooded rice soils. In: Hauk RD, editor. Nitrogen in crop production. Madison, Wisconsin, USA: American Society of Agronomy. pp. 349362.

Wittwer SH, Bukovac MJ, Tukey HB. 2002. Advances in foliar feeding of plant nutrients. In: McVickar MH, editor. Fertilizer Technology and Usage. Madison, WI: Soil Science Society of America. pp. 429-455.

Yoshida S, Forno DA, Cock JH, Gomez KA. 1976. Laboratory Manual for physiological Studies of Rice. 3rd ed. International Rice research Institute, Manila, Philippines.

Yoshida S. 1981. Physiological analysis of rice yield. In: Fundamental of Rice Crop Science. IRRI, Los Banos, Philippines. 269: 91-98.

Zhang Q. 2007. Strategies for developing green super rice. P. Natl. Acad. Sci. USA. 104: 16402-16409. 